\title{
Winthrop College in the Sixties: Campus Protests, Southern Style
}

\author{
A.J. Angulo \& Leland Graham \\ Winthrop University
}

\section{ABSTRACT:}

The story of student protests during the 1960s is often told from the perspective of large research universities. This paper seeks to contribute to the literature by examining the way students at Winthrop College - a small, regionally distinct, liberal arts institution - handled the dramatic changes that unfolded across the decade. Founded as a normal school in late nineteenth century South Carolina, Winthrop students witnessed little change to its white, southern, women's college traditions throughout the first half of the twentieth century. By the end of the sixties and early seventies, the college had integrated, eliminated many of the rules and restrictions that had governed student life, and had become coeducational. This paper explores these transitions and how students agitated for or responded to fundamental changes to Winthrop's institutional identity.

RÉSUMÉ:

L'histoire du mouvement contestataire étudiant des années 1960 est souvent relatée dans le contexte des grandes universités. Cette étude apporte un nouveau point de vue en exposant la manière dont les étudiants de Winthrop College — une petite institution régionale offrant un programme de culture générale - ont vécu les changements dramatiques au cours de cette décennie. Fondé en Caroline du Sud à la fin du dix-neuvième siècle, ce collège était à l'origine une école normale de filles. Les étudiantes de Winthrop connurent peu de changements dans cette institution pour femmes blanches du Sud des États-Unis au cours de la première moitié du vingtième siècle. Cependant, à la fin des années 1960 et au début des années 1970, le collège élimina les pratiques raciales, abolit plusieurs règlements et restrictions qui régulaient la vie étudiante tout en devenant un collège mixte. Cet article s'intéresse à ces transitions et à la manière dont les étudiants ont accepté ou réagi aux changements importants apportés à l'identité institutionnelle de Winthrop.

Winthrop College was founded in Rock Hill, South Carolina as a normal school for women in the late nineteenth century. During the first half of the twentieth century, the institution kept alive traditions established since the institution's founding, such as uniform dress codes for students, parietals, segregation, and single-sex education. Many of these traditions came to an end during the sixties. ${ }^{1}$ 
Recent trends in the sixties literature suggest a growing interest in developments at institutions like Winthrop. The trend builds on the well-worn scholarship on Berkeley and Ann Arbor, Oxford and Athens. The focus has turned from large state institutions to small and medium sized colleges and universities, denominational institutions, women's higher education, and regional patterns of campus protests. Papers presented at the University of South Carolina's 2010 Conference "Student Activism, Southern Style: Organizing and Protest in the 1960s and 70s" delivered on many of these emerging research interests. ${ }^{2}$

While the "sixties" story had been told many times, Winthrop, as a case study, offers the perspective of a woman's college in the South. It is a perspective that appears infrequently in dominant accounts of campus tumult during the period. This article will focus specifically on how the institution shucked its exclusively white, southern belle (or, as they called it, "fairest flower") image and exchanged it for something radically different. It suggests that campuses like this, framed largely by race, gender, and region, wrestled with fundamental questions of identity and, at times, adopted peculiar means for responding to the times. This study will take a closer, internalist look at Winthrop students during the sixties and early seventies in relation to three main developments. First, the paper will explore the topic of integration. Emphasis will be placed on student responses to the admission of Winthrop's first African American students. Second, the paper will examine how in loco parentis - or campus restrictions normally imposed by parents on such matters as dress, dating, and access to automobiles - in large measure came to an end. Attention will be given to the regulations that governed student life and the process that removed them from campus policy. And finally, the paper will describe events and crises, some of which were manufactured by the campus itself, leading to the decision to make Winthrop a coeducational institution. While the final decision came in the early seventies, students and administrators had taken unusual steps to press the issue since the very beginning of the sixties. ${ }^{3}$

\section{Integration and the Invisible Woman}

Integration at Winthrop began just after two major developments in South Carolina higher education. The University of South Carolina and Clemson University admitted their first African American students in 1963. Integration in Columbia, with the admission of Robert Anderson and two others, was marked by hostility and disruption. Opponents used racial epithets, threats of assassination, and explosives to intimidate them. The case in Greenville, with Harvey Gantt the same year, was peaceful by comparison. Gantt was welcomed into campus organizations and graduated with a degree in architecture with honors. Winthrop students saw the writing on the wall and recognized that sooner or later their institution would follow suit. The question that remained was: would it be a disruptive or peaceful process? ${ }^{4}$

After USC and Clemson had integrated, but before Winthrop had officially taken up the issue, Winthrop students expressed conflicting views on the matter. Some were "still violently opposed" to integration, explained one student from Columbia. 
She felt certain there would be be a "barrier for a Negro student" at Winthrop. This raised the possibility that events in Rock Hill might turn out like those at USC. Even undergraduates who didn't oppose the idea understood the heated passions, and potential for violence, surrounding desegregation. The idea alone introduced conflicts between students and their parents as they considered the question in relation to the all-female institution. "My mother and daddy," commented one Winthrop student, "would never agree with me. I was brought up on a strict segregation diet, but I have to make up my own mind." Thus, violent opposition, barriers, and family traditions represented part of what concerned Winthrop students. ${ }^{5}$

Others thought the time had come for their institution to take up the concern, but with certain limits. "We're ready for integration," noted a Winthrop junior, "but she will have to come from an exceptional family to win acceptance." While it's unclear what counted as "exceptional," one thing was certain — admission of an African American student would be based on separate standards exceeding those placed on average Winthrop students. The general tenor of students in agreement with the idea of accepting the first black student at Winthrop was qualified approval. She would have to be "neat and clean" and even then, declared one student, "I don't really know how I would feel about a Negro roommate." A few others claimed that it would be acceptable to have one in the "next room" or "one next door" in the dorms, but all gave the suggestion that such a student would certainly be "an object of curiosity."

In short, Winthrop's campus climate in the lead up to accepting its first African American was mixed. Some stated explicitly that "I don't believe in integration" and that "I am opposed to integration," stirring up the possibility of violent confrontation. Others called for a "peaceful coexistence" and that "[i]t's coming and there's nothing to do about it." Given the events at USC and Clemson, it remained unclear which way Winthrop would go. ${ }^{7}$

When Cynthia Plair Roddey applied to Winthrop in the spring of 1964, everyone had a chance to find out. Roddey didn't apply to force changes at the historically segregated institution. She claimed that the recent moves by USC and Clemson had little or nothing to do with her application. There were no civil rights organizations backing her. Rather, few knew of her intent to apply. The driving motivation for her was convenience and practicality. ${ }^{8}$

Roddey lived in Rock Hill and wanted a graduate degree in library science. She had completed an undergraduate degree in English and Religion with honors from Johnson C. Smith University in Charlotte, North Carolina. She had also received certification to teach in elementary school. While teaching for the York County School District, she decided to pursue graduate work to become a school media specialist. The closest black college with the appropriate program for her was Benedict College in Columbia, approximately seventy-two miles away. Married and with two small children, Roddey weighed the practical considerations as well as the costs. In the end, she viewed the distance and burden as too great and decided instead to apply to Winthrop. She lived almost "across the street" from the campus. For Roddey, the issue was one of proximity and convenience. For Winthrop, consideration of her application meant balancing the interests of constancy and change. Her admission would upset supporters of the 
institution's longstanding segregation policies, raising questions about institutional mission and character. The balance tipped in favor of change and Roddey began her studies at Winthrop during the summer session on July 20, 1964 . $^{9}$

The summer session had only four hundred students (as opposed to 2000 during the regular academic year) and therefore served as a barometer for Winthrop officials. If things went smoothly during the summer, she could attend as a regular student starting the fall of 1964 . For her first day, law enforcement sealed off all entrances to the campus with the exception of one and stood guard at the others. Officers patrolled the campus and prepared for a large-scale disturbance. Friends, neighbors, and family members guarded her home in Rock Hill with shotguns. All were ready for trouble, but none came. ${ }^{10}$

But there was no warm reception either. As Roddey later described it, Winthrop students silently protested her admission to Winthrop. Rather than experiencing the shouting of racial epithets and other hostile gestures as at USC, students generally ignored her presence. "It was like being isolated, the invisible man syndrome," she said. During her three years at Winthrop, she spoke with only two students, one of them a traditional student who spoke to her only in the bathroom between classes and the other a non-traditional student who was divorced and with children. Silent integration, therefore, was the response to integration followed at Winthrop. ${ }^{11}$

During Fall 1964, two more African American female students joined Roddey. By the time Arnetta Gladden and Delores Johnson arrived on campus that September, however, the press found it had little to report. Their orientation and registration went smoothly, and the local paper was left to remark that they were "neatly dressed" and spoke to those around them in line. In a letter to the Board of Trustees, President Davis reveled in the success of Winthrop's integration. It had occurred "without incident and with a minimum of press notice... the Press has accepted our stand that the College was integrated last summer, and has treated the fall semester developments as a more or less routine matter." The white students "showed little reaction... [and] appear to accept their presence casually." Nevertheless, Gladden and Johnson experienced the same social ostracism without the benefit Roddey enjoyed of being able to return home after classes. Both girls were given single rooms that shared an adjoining bathroom. Presumably, the college wanted to keep the African-American coeds as separate as possible from their white dorm-mates. Indeed, hall meetings were almost the exclusive venue for interacting or socializing with their fellow residents. Further, the college subjected Gladden and Johnson's visitors, especially black males, to increased scrutiny and even harassment. Police frequently trailed and questioned their male visitors. This heightened response stemmed, at least partially, from a rumor that ran rampant their first semester. According to several letters from concerned parents, "three negro men entere[d]" Lee Wicker dormitory and left campus in the company of three white girls, "paired off as dates." President Davis replied to these letters, claiming that the rumor was "absolutely without foundation. Inter-racial dating is contrary to the policies of Winthrop College." Since the student handbook lacked any mention of interracial dating, one way or another, Davis most likely was referring to an implicit, unspoken code when making this claim. ${ }^{12}$ 
The isolation continued for years after these first African American students enrolled, especially when it came to life outside the classroom. Some had begun calling certain isolated dorm areas by the students isolated in them. "Roddey dorm was formerly called West," noted one student, "and Breazeal was East dorm." It wasn't until Fall 1968 that white, out-of-state students like Nancy Chap (from Vermont) and Kay Swendseid (from Ohio) had taken the "giant step" toward interracial rooming. The move won them a special write up in the campus paper. Chap stated that she didn't request an African American roommate; what she wanted, rather, was "an amiable and intelligent roommate with no regard to race." Swendseid, however, did request a black roommate in her application. She wanted "a roommate who could enlighten me on the background of the Negro; his hardships, his struggles, and his never-ending fight for freedom." What surprised her most was the callous disregard for these struggles among her peers. "The girls here at Winthrop," she stated, "pretend that racial problems do not exist." Despite these efforts, little had changed for the increasing minority population arriving on campus by the end of the decade. By 1970, black students had organized "The Ebonites," a student group dedicated to promoting their own social interests and activities. Since "white girls didn't speak" to them, they turned to forming their own social networks and establishing separate organizations. ${ }^{13}$

Silence, therefore, functioned as a socially acceptable form of protest against integration on this southern woman's college. It created separate spaces between black and white and to a large degree recreated a "separate but equal" doctrine at Winthrop, long after the courts had buried Plessey.

\section{The Push Against In Loco Parentis}

Unlike the battles over integration throughout the U.S, there were no documented cases of students being "violently opposed" to doing away with some of the more stringent codes governing student life. Students almost uniformly agitated against Winthrop's version of in loco parentis. When it came to student life issues, they dropped the "silent" mode of protest for one that was much more vocal and active by comparison.

At the very start of the decade, Winthrop students were held to fifties' era regulations. They followed a dress code that required formal attire on campus and in "public places in Rock Hill and vicinity" and disallowed "blue jeans, slacks, leotards, pajamas, Bermuda shorts or shorts" except for a few informal occasions. Seniors were the only students who could bring cars to campus, and even they couldn't drive their vehicles past 8:30 p.m. without special permission. If students wanted to walk to the campus lake, they had to sign out of the dorm in groups of four or more and had to be accompanied by a chaperon if after 6:00 p.m. or 7:30 p.m., depending on the time of year. Contingent on parental approval, Winthrop regulations permitted "weekends" (overnight absences on weekends only) on a sliding scale. Freshmen had three per semester, sophomores four, juniors five, and seniors six. Otherwise, during the week, they were required to be back in their dorms by dorm closing — normally 7:30 
p.m. - with few exceptions which allowed groups of students with a certain grade point average to attend specific functions until 10:30 p.m. While juniors and seniors enjoyed the privilege of a handful of lates or "late permissions" per semester, virtually all dating and other social activities were to occur between 9:00 a.m. and 7:30 p.m. Weekend hours were more lenient, with Friday evenings extended to 11:00 p.m., Saturday till midnight. Any deviations from these regulations required the approval of the Residence Hall Counselor. ${ }^{14}$

In their effort to overturn these regulations, student leaders waged a war of attrition between 1960 and 1970. Tensions first began to heat up when students returned to Winthrop after December Break in 1960; they discovered that the administration had enacted a new rule forbidding televisions in dorm rooms. Students would only be allowed to watch television in communal areas during specific hours. Students protested their treatment as juvenile in letters to The Johnsonian, suggesting that upperclassmen were responsible enough to regulate their own television watching. In fact, their push coincided with newly appointed President Charles Davis's desire to modernize Winthrop's rules. That November, he appointed a joint student/faculty committee to make recommendations for a new code of conduct that would place " $[\mathrm{m}]$ ore responsibility on the student for the student's own proper conduct and less on rules and regulations, so that the student has the opportunity to grow morally as well as mentally and academically." The new code reached the Board of Trustees by March. It specifically permitted televisions in dorm rooms. It permitted both juniors and seniors to bring cars to campus; it allowed any student to visit the lake before sunset, without restriction; it extended dorm closing to 11 p.m. every day, except Saturday when they closed at midnight, and established uniform "late permissions" to four "twelve o'clocks" and four "one o'clocks" per year. It added specific places on rooftops and elsewhere (out of view) for students to sunbathe on campus. After brief deliberation, the Board approved the revisions. Although this represented a radical departure from previous handbook regulations, these concessions proved to be just the beginning. ${ }^{15}$

Feeling empowered with this major victory, students turned from demanding general concessions to claiming specific rights. The first right they claimed was the right to drink alcohol. They questioned student handbook regulations on drinking by students while under the authority of Winthrop, an authority which "begins when a student leaves her home to come to Winthrop and continues until she returned to her home and the authority of her parents or guardian." Students found particularly onerous and capricious a rule stating that "the possession or use of alcoholic beverages on the Winthrop campus and in the Rock Hill area (radius of 25 miles) is strictly prohibited." Beyond that radius, students had permission to drink. Student government leaders responded to these limitations by drafting a bill in Spring 1965 to repeal the twenty-five mile radius drinking restriction. Student interviews conducted by The Johnsonian revealed that most students favored repealing the rule, arguing that students were mature enough to make their own decisions and that the current rule actually promoted drinking and driving as student ventured beyond the radius to imbibe. The bill passed a Student Government Association (SGA) vote and cleared a 
faculty-student committee before landing on President Davis's desk. Davis's concerns about publicity generated by the push led him to veto the bill "for the time being." Cued by Davis's explanation, The Johnsonian published no articles, editorials, or letters on the subject for a year. The next fall, Davis quietly repealed the radius, and eighteen year old freshmen entering Winthrop in 1966 were now permitted to drink in Rock Hill. ${ }^{16}$

Meanwhile, students agitated for changes to how Winthrop regulated their movement on and off campus. In 1962, students claimed and won the right to "blanket permissions," permissions signed by parents that gave their daughters permission to use their own discretion when leaving campus. In Fall 1966, however, the administration altered the blanket permissions policy, forbidding students from going to hotels or motels, house parties, or a destination other than their home for vacation without specific parental permission. The Johnsonian once again spearheaded the student protest, arguing that the new regulations violated the spirit of blanket permissions and insulted both students and parents who had signed the forms. The administration made matters worse by instructing the SGA to begin "spot checking" students who had signed out of campus, calling the location listed on the form to ensure that students had not lied. Students flooded the campus paper with calls for action and activism, but the paper itself chastised students for believing that a few "letters to the editor are all that can be done to eliminate the [dorm] policy. ... Motivated students must then convert words into acts." If reforms faced opposition on campus, they could turn to their senators in the state legislature to demand changes to the policies. And even if such legislation is "vetoed by the administration," students should realize that the legislation could be reintroduced as often as desired and "eventually, after much student pressure, the policy, as with the drinking rule, may be quietly eradicated." This was their stance and their hope - that that they could wear the administration down through incremental changes year after year. Eventually, The Johnsonian called for a compromise with the administration, asking for a new blanket permission form that would allow parents the additional option of specifically excluding those locations targeted by administration. The administration ultimately agreed to this suggestion and issued new permission forms in Fall 1968. Students could now secure the option of self-regulation in terms of place and time without interference from Winthrop officials. ${ }^{17}$

While defending the right of alcohol consumption and self-regulation brought students together, the struggle over dress codes created some divisions among the student body. As late as the 1950s, Winthrop girls wore uniforms on and off-campus. Before the major revisions of 1961, students were required to wear formal attire ("afternoon dress, heels, and hose" and sometimes hats) on many occasions, and skirts or dresses for almost everything else. The new code attempted to show some flexibility by stating that "students are expected to dress appropriately for all occasions." The vague rule didn't last long. The Johnsonian questioned what counted as appropriate and began to push the boundaries, asking, at first, only for permission to wear "Bermuda shorts" in the library during the exam period. SGA disagreed and proposed stricter dress standards that prohibited wearing sweatshirts or untucked 
blouses in the dining hall. The Johnsonian accused SGA of being mired in "trivialities." Neither student group had much success one way or the other until 1967 when Winthrop administrators entered the dress code fray by stating that "dress is a matter of taste, and taste cannot be legislated." This held true, of course, unless Winthrop decided to legislate the details of taste; and the very same handbook did just that. Students were still required to wear skirts and dresses for class, weekends in the dining hall, and in downtown Rock Hill; otherwise, tidy clothes with were now permissible elsewhere. It wasn't until the end of the decade that Winthrop had essentially freed its girls from restrictive dress codes. By the fall of 1972, all mention of what they should and should not wear no longer appeared in the handbooks. ${ }^{18}$

The key transformation that occurred with in loco parentis at Winthrop, beyond actual changes to policy, was in the way students looked at them. The topic had taken a legal and constitutionally-based turn. The lessons of integration had taught them that institutions of higher education change to comply with state law. They cast many of the existing codes of conduct as unconstitutional, claiming that these rules should be "revised in accord with South Carolina state law" including alcohol consumption and self-regulating hours granted by blanket permissions. Winthrop's campus paper fueled campus protests and the SGA passed proposals that won administrative approval. With the enactment of such permissions, students had largely overturned in loco parentis at Winthrop. Students were no longer subject simply to the "authority of Winthrop" but rather to the "laws and regulations of the college, city, state, and nation;" any violations would be adjudicated "with due process observed." Although activism continued, students turned their attention to remaining on-campus rules and regulations. The final vestiges of in loco parentis faded as the college prepared for coeducation; the administration realized it would have to liberalize the cloistered environs of a women's college as it prepared to welcome male coeds. Administration soon revoked restrictions on attending house parties and allowed all students to bring cars to school. Winthrop granted self-regulating hours to seniors, with parental permission, in 1970. The college gradually extended this level of autonomy to all students, ultimately without requiring parental permission, over the next five years. Ultimately, the opposition of trustees and alumnae proved insufficient to maintain the ban on alcohol possession. Where the previous handbooks "prohibited... the consumption or possession of alcohol beverages on campus," the 1974 handbook simply noted that "the College does not sanction the consumption or possession of intoxicants." A year later, alcohol was explicitly permitted in dorms and specific areas on campus, and the student union sold beer and wine in its canteen. By the second year of coeducation, the concept of in loco parentis had entirely disappeared from Winthrop's campus. ${ }^{19}$

\section{The Coeducation Crisis}

While Winthrop integrated and underwent a wholesale revision of its student regulations, it also began to turn away from being a single-sex institution. The process took an unusual turn in relation to the first male student to attend Winthrop. The struggle 
for his diploma came after a decade of changing perceptions of coeducation at the college and increasing economic pressure faced by its administrators.

A few months before Roddey stepped on to the campus in 1964, Winthrop students conducted a self-study on what they thought about coeducation. It came at a time of declining enrollments and a sea-change in women's higher education nationally. Out of approximately 90 institutions in existence in the fifties, there were by the opening of the 1960s an estimated 60 women's colleges left. Administrators at Winthrop had been conducting a study of the economics of coeducation and the possibility of changing the institution's charter and facilities to accommodate male students. The student survey, born out of this context, was based on a random sample delivered to fifty-five members of each student class. Based on this sample, the survey found that Winthrop students overwhelmingly rejected the idea of coeducation. Seventy-nine percent of students preferred single-sex education to coeducation. The results showed that most of the existing support for coeducation came from seniors (thirty-five percent) and juniors (twenty-five percent) years, with the least support coming from sophomores (fourteen percent) and freshmen (sixteen percent). ${ }^{20}$

Reasons students gave for rejecting or supporting the idea of turning Winthrop into a coeducational institution varied widely. Those who rejected the idea valued having a state-supported institution devoted exclusively for women. Having men on campus would increase campus expenses for male sports and dormitories, increase competition in running for student office, and create tensions in the classroom - all common arguments for the women's colleges. Those in favor of coeducation welcomed the challenges as part of preparing for the real world. Spirited classroom debates and social activities would bring about positive changes to the campus. What's clear from the survey and from the responses is that strong opposition to coeducation came most powerfully from the bottom (youngest classes) up and they had little interest in seeing their institution change. ${ }^{21}$

By the time those freshmen made it to their senior year, Walter H. Schrader, Jr. had quietly taken enough summer and evening courses in a graduate program to qualify for a degree. His presence as a graduate student had been free of controversy and had not raised flags regarding the institution's charter as a woman's college. It also had not disrupted student life. But when he applied for a degree in January 1966, the Graduate School rejected his application. Harold Gilbreth, Dean of the Graduate School, stated that Winthrop couldn't award degrees to male students, regardless of courses taken and credits accumulated. Males had never been awarded a Winthrop degree and Schrader would not be the first, or so the official line suggested. Behind the scenes, activism and change were brewing in the administrative halls of the institution. Stagnant and declining enrollments prompted administrators and the Board of Trustees to consider making the institution coeducational. College officials had learned of five hundred males within commuting distance who had expressed interest in attending Winthrop. Schrader's application fueled the College's efforts to remove the obstacle preventing these potential males from attending. Administrators supported a bill before the state legislature allowing all Winthrop students, including males, to receive degrees for programs completed through evening, summer, and extension coursework. ${ }^{22}$ 
The bill to make the institution partially coeducational died, but interest in the topic only intensified. In late 1968, Schrader decided to sue Winthrop. His complaint against the institution was straightforward. He'd been allowed to enroll as a student and complete programmatic coursework in a graduate program. Any denial of a degree from Winthrop, based on sex, constituted a violation of the Fourteenth Amendment equal protection clause. With a suit before them, Winthrop officials and state politicians moved quickly to resolve the crisis. It appeared that Winthrop faced a coeducation threat from the outside and the institution requested legal support to address the matter. Winthrop succeeded in getting approval for what came to be known as the "Trial Year." State legislators passed a bill that allowed Winthrop to award degrees to allow enrollment of males for only the academic year 1969-1970. Schrader was awarded a degree in August 1969 and fifty male students enrolled at the college that academic year. ${ }^{23}$

Student attitudes toward coeducation came into focus and were used to argue each side of the matter. Charles Ellis, spokesperson for The Taxpayers Committee for a Better Winthrop, argued in 1969 that Winthrop should remain a woman's college because a poll he had conducted showed an overwhelming majority of students wanted to keep the institution all-female. While failing to provide statistics to the legislative committee examining the issue of coeducation at Winthrop, he nevertheless believed such was the case.

Students disagreed. The student paper wrote that " $[\mathrm{t}]$ his year we have reached a mutual decision and have decided to make our ideas known about co-education. WE ARE FOR IT." Winthrop should be "changing with the times" and not burdening "taxpayers" for "more money for additional coeducational colleges" when Winthrop could easily be converted for the purpose. ${ }^{24}$ The paper voiced opposition to external forces that influenced the course of Winthrop's future.

Alumnae shudder at the idea of coeducation. Some of them think free communication between Winthrop women and their professors would be prohibited with the presence of male students. Come on now. . . Fairest Flowers. . . Very few women go throughout life without coming into contact with male opinions. The presence of men might just stimulate a greater flow of free communication between faculty and students at Winthrop. ${ }^{25}$

This represented the views of many student leaders on campus at the time and contradicted what the "Taxpayers Committee" had suggested. Opposition to coeducation seemed like "emotional sentimentalism" to Student Judicial Board Chair. The Student Senate President, meanwhile, claimed that women aren't properly prepared in "an all-girls college." The Interfaith Council President added to the complaints and noted that developing platonic relationships was "vital to well-rounded maturity" and Winthrop girls have "little, if any, opportunity" for these sorts of relationships. ${ }^{26}$

David Gover also disagreed with Ellis. As a professor of sociology at Winthrop College, he wanted data to confirm the assertions being used to argue for one point or the other. What he found directly conflicted with Ellis's position, at least the position 
that students "overwhelmingly" sought to keep Winthrop an all-female institution. Gover conducted two surveys of students to gauge their sentiments about the topic, one in November and the other in December of 1969. Schrader had already received his degree and the so-called "Trial Year" would end the following May. Between the two surveys, he collected 760 student responses on Winthrop and coeducation. Over half of respondents (fifty-two percent) believed coeducation at Winthrop would be beneficial to the state. A slightly higher number (fifty-four percent) stated that unlimited coeducation was the best course of action for Winthrop. The student body, Gover showed, was evenly divided. But the slight majority welcomed change. ${ }^{27}$

While Winthrop students began to warm to the idea of coeducation, those denied admission became fervent activists. Ten males from York County wanted to enroll as freshmen in August 1970. The bill to renew the trial year had become mired in the political process and didn't appear to be gaining any traction. These students followed in Schrader's footsteps, hired the same legal firm, and sued the college. As the case wound its way through a federal appellate court and, ultimately, the United State Supreme Court, the final ruling found compelling the argument that since these men could attend other publicly-funded institutions in the state there was no actual discrimination. That they lived in Rock Hill and wanted to attend Winthrop was immaterial. The potential freshmen students lost an expensive legal battle. The experiment in coeducation was to be discontinued after the trial year. ${ }^{28}$

After persistent lobbying on the part of Winthrop officials, Board of Trustee members, and the Governor of the state of South Carolina, state legislators capitulated in 1972 and granted limited coeducational status to Winthrop. They stipulated that male students would be permitted to attend as of their junior year, with the first two completed elsewhere. Summer school was exempted from this stipulation. The Title IX amendment to the Higher Education Act in the same year made the change imperative. Federal assistance programs would only go to schools that made their institutions available without discrimination on the basis of sex. A bill resolving to allow the Board of Trustees to decide the matter of coeducation was signed into law early in 1974 and on March 19 of that year Winthrop's Board met and established full coeducation for the institution. ${ }^{29}$

Behind the scenes, during the coeducation court battles, Winthrop had taken an active role in manufacturing its own crisis, particularly when it came to Schrader's case as well as the York County Ten. Years after the controversy settled, Schrader stated that he'd been a "guinea pig" selected by college officials to test the legal limits of coeducation at the institution. He took legal action against Winthrop under the advisement and direction of the President and Board of Trustees. When Schrader applied for his degree, President Davis's first reaction was that he'd "met every requirement and it does seem a little silly to me that we can't grant him his degree." Davis was hardly alone in the administration. Board of Trustees Chair William Grier not only thought it was silly. It was a matter that needed action. According to Schrader, Grier "hired the best lawyer in Columbia to represent me." The trustee chair and a small group of the institution's executives "quietly collected" funds "to engage an attorney" for the purpose. By hiring and dealing directly with Columbia attorney 
Terrell Glenn, Winthrop orchestrated the suit against itself. Schrader described being almost left out of the process and that he "really never had any dealing with him [Glenn] at all - it was all taken care of for me. I never had to pay any money or anything." Even if the federal court gave Schrader "an adverse ruling," Davis made "promises of the money and a little more than really needed" to take the case to the Supreme Court. With declining enrollments, Schrader understood Winthrop's decision to sue itself as an attempt to enact change in a politically charged environment that would not permit coeducation on the scale that Winthrop wanted or, for economic reasons, needed to implement. ${ }^{30}$

That wasn't the last time Winthrop paid to sue itself for coeducation. When the trial year ended with Schrader receiving his degree but without a satisfactory longterm resolution, the York County Ten began the Winthrop Students for Coeducation campaign. Student David Long led this campaign with generous support from the college community. Both Winthrop's Public Relations Office and Trustee William Grier quietly bankrolled Long's effort in mailing nearly 10,000 letters along with postage-paid, self-addressed envelopes to potential donors. "We are asking you, a citizen who has concern for South Carolina's educational system," began Long's mailer, "to support us in our endeavor to bring coeducation to Winthrop College." Donations, he explained, would help pay for the services of attorney Terrell Glenn in "a Class Action suit" to overturn the college's single-sex status. The campaign proved highly effective. Long and his committee raised more than the needed amount to pay the attorney fees. Approximately half of the funds needed came from Winthrop's faculty and staff. ${ }^{31}$

\section{Conclusion}

Taken together, these themes — silence, social codes, and law suits - offer a portrait of the forces shaping Winthrop's campus culture during the sixties. Students had mixed feelings about integration before it happened and they turned silent once it did. The environment, while unwelcoming to Roddey, was free of open hostility or violence. If anything, Winthrop's integration process stood somewhere between the events that played out in Columbia and Greenville. As Winthrop's student body changed, so too did the rules that regulated their campus lives. They took on the dorm policies and behavior codes of the fifties and, through a war of attrition, advocated for a blanket policy rule that would permit for self-regulation of time and place. The leading activists came in the form of student newspaper editors and elected members of the student government. They couched their stance in terms of constitutional and civil rights and ultimately won approval for the policy they sought. And when it came to coeducation, Winthrop's activists were students-to-be rather than existing students. Campus sentiment on the idea of males at Winthrop certainly changed, dramatically, across the sixties. With little widespread support for the idea at the beginning of the decade, Winthrop women warmed to the idea by the end. The legal push for coeducation at Winthrop, although coming from males wanting to attend the institution, was orchestrated and engineered by campus 
administrators who faced economic uncertainty. As such, Winthrop's coeducation crisis was manufactured.

In the end, Winthrop women of the sixties lived through the most vital changes in college's history. They integrated, challenged the accepted norm of in loco parentis, and allowed men to come through their gates - all through a mixture of silence, creative and persistent student leadership, and legal action.

But Winthrop was one of many institutions in the South to be placed between a rock and a hard place. Mississippi State College for Women, Texas Woman's University, Sweet Briar College in Virginia, and Columbia College in South Carolina, among others, all shared similar circumstances. On the one hand, they had an identity that worked well for them as a reputable white women's college that catered to southern norms and sensibilities. To change this identity was to court uncertainty and perhaps even closure. On the other hand, they faced declining enrollments as increasing numbers of woman made inroads at large state institutions. Without change, they faced a slow death. Student government and the student newspaper proved to be the most effective means of change for these students, as they served similar roles for women's colleges in places like Mississippi, Texas, and Virginia, especially in creating "forums" for changing in loco parentis by the late 1960s. At Winthrop, the student government lobbied administrators to change policies and their victories fueled student sentiment for greater change. The Johnsonian, meanwhile, made sure the latest developments of student government were known to the campus. In both, the specific tone and character was persistent but non-confrontational. It was a war of attrition that they waged. Not all, of course, agreed with the direction this particular campus was headed during these tumultuous years. Some repeated the expectations placed on these women - that that silence was a virtue. As one student declared, "I have often regretted my speech, seldom my silence." Nevertheless, the change that many on the campus wanted and that brought so many uncertainties came to fruition by the end of the sixties. ${ }^{32}$

\section{Notes}

1 For an account of Winthrop's early history, see E. Thomas Crowson's The Winthrop Story, 1886-1960 (Baltimore: Gateway Press, 1987).

2 For a sampling of recent trends in the literature, see the following: Linda Eisenmann, Higher Education for Women in Postwar America, 1945-1965 (Baltimore: Johns Hopkins University Press, 2006); G. Thomas Edwards, "Student Activism at Whitman College and Willamette University, 1965-1971," Pacific Northwest Quarterly 99 (Fall 2008): 173-180; Anthony J. Dosen, Catholic Higher Education in the 1960s: Issues of Ideas, Issues of Identity (Charlotte: Information Age Publishing, 2009).

3 Ross A. Webb, The Torch Is Passed: A History of Winthrop University (Mansfield, Ohio: BookMasters, 2002); Amy Thompson McCandeless, The Past in the Present: Women's Higher Education in the Twentieth-Century American South (Tuscaloosa: University of Alabama Press, 1999); see also Ross Webb's unpublished multi-volume manuscript of Winthrop University's history located in the Dacus Archives, Winthrop University, Rock Hill, SC [hereafter, DAWU]. One of the most significant issues of the era not 
discussed in this paper was the Vietnam War. Although a tremendous presence at other campuses, it appears to have affected Winthrop only marginally. The topic surfaces in the student periodical only twice (to any substantial degree) in relation to two polls. In 1965, sixty-two percent of students surveyed approved U.S. policy in Vietnam. A mere 17 out of $474(0.04 \%)$ approved of demonstrations, draft-card burning, and sit-ins at military installations. In 1967, sixty percent of students favored a restricted version of the draft for women. See, "Poll Shows Student Approval of U.S. Policies in Viet Nam," The Johnsonian, November 12, 1965; "Recent Survey on Campus Reveals Students Favor Accepting Draft Call,” The Johnsonian, April 10, 1967.

4 The scholarship on desegregation in southern higher education is still mainly found through institutional histories. In the case of South Carolina, see Henry H. Lesesne, $A$ History of the University of South Carolina, 1940-2000 (Columbia, S.C.: University of South Carolina Press, 2001), 146-149; Leslie Wallace Skinner, "Sibling Institutions, Similar Experiences: The Coeducation and Integration Experiences of South Carolina's Clemson and Winthrop Universities" (Ph.D. diss., University of South Carolina, 2002); Peter Wallenstein, "Higher Education and Civil Rights: South Carolina, 1860s-1960s," History of Higher Education Annual 23 (2004): 1-22.

5 "Winthrop Girls Say They Are Ready for Integration of College Student Body," Evening Herald [Rock Hill], February 16, 1963; Winthrop Girls Ready to Integrate Quietly," Charleston Courier, February 21, 1963.

6 "Winthrop Girls Say They Are Ready for Integration of College Student Body," Evening Herald [Rock Hill], February 16, 1963; "Winthrop Girls Ready to Integrate Quietly," Charleston Courier, February 21, 1963.

7 "Winthrop Girls Say They Are Ready for Integration of College Student Body," Evening Herald [Rock Hill], February 16, 1963; "Winthrop Girls Ready to Integrate Quietly," Charleston Courier, February 21, 1963.

8 Cynthia J. Wilson, "Winthrop's First Black Student Speaks Out," The Johnsonian, January 29, 1979; Retha Hill, "Winthrop Integration Quiet in '64," Evening Herald [Rock Hill], February 15, 1985. These sources offer a retrospective on why Roddey applied and are derived from two interviews with her conducted in the seventies and eighties. No contemporary article or sources are available on her reasoning because she never gave interviews as a student and tried to avoid scrutiny. Because she was not one of three NAACP backed candidates, Winthrop accepted her during the summer session so the action would be perceived as voluntary and not dictated by outside pressure. See, "NAACP Leader Says Winthrop to Integrate," The State [Columbia], June 15, 1964.

9 Cynthia J. Wilson, "Winthrop's First Black Student Speaks Out," The Johnsonian, January 29, 1979; Retha Hill, "Winthrop Integration Quiet in '64," Evening Herald [Rock Hill], February 15, 1985; see also, "Rock Hill Teacher Is First Negro at Winthrop," Evening Herald [Rock Hill], July 20, 1964; "Winthrop Accepts Negro Coed," Charleston News and Courier, June 18, 1964; "40 Years Later," Evening Herald [Rock Hill], July 11, 2004.

10 Cynthia J. Wilson, "Winthrop’s First Black Student Speaks Out," The Johnsonian, January 29, 1979; Retha Hill, "Winthrop Integration Quiet in '64," Evening Herald [Rock Hill], February 15, 1985; see also, "Rock Hill Teacher Is First Negro at Winthrop," Evening Herald [Rock Hill], July 20, 1964; "Winthrop Accepts Negro Coed," Charleston News and Courier, June 18, 1964; "40 Years Later," Evening Herald [Rock Hill], July 11, 2004.

11 Cynthia J. Wilson, "Winthrop’s First Black Student Speaks Out," Johnsonian (January 29, 1979); Retha Hill, "Winthrop Integration Quiet in '64," Evening Herald [Rock Hill], February 15, 1985; see also, "Rock Hill Teacher Is First Negro at Winthrop," Evening Herald [Rock Hill], July 20, 1964; "Winthrop Accepts Negro Coed," Charleston News and Courier, June 18, 1964; "40 Years Later," Evening Herald [Rock Hill], July 11, 2004. 
12 “Two Negro Girls Winthrop Students," Evening Herald [Rock Hill], September 16, 1964; Charles Davis to the Winthrop Board of Trustees, September 19, 1964, Board of Trustees File, DAWU; Interview of Arnetta Gladden Mackey by Martha Williams, August 1975, O.H. 17, Winthrop Oral History Collection, DAWU; Interview of Arnetta Gladden Mackey by Steve McKnight, 30 April 1981, O.H. 126, Winthrop Oral History Collection, DAWU; Mary Moss to Ida Gibson, November 9, 1964, Integration File, DAWU; Charles Davis to [Redacted], December 10, 1964, Integration File, DAWU; see also, Leslie W. Skinner, "Sibling Institutions, Similar Experiences: The Coeducation and Integration Experiences of South Carolina's Clemson and Winthrop Universities" Ph.D. diss., University of South Carolina, 2002).

13 "'Good Old Days' Are Gone, But Who Misses Them!," The Johnsonian, March 13, 1964; "Interracial Rooming Viewed," The Johnsonian, September 30, 1968; "Racism Exists," The Johnsonian, November 2, 1970.

14 Winthrop University, Student Handbook, 1959-1960.

15 "Letters," The Johnsonian, February 26, 1960, March 4, 1960 and December 6, 1960; "Ancient Rules Face Modern Jury," The Johnsonian, December 2, 1960; Board of Trustees Minutes, Winthrop College (March 1961); Board of Trustees Minutes, Winthrop College (June 30, 1961).

16 "Major Rule Changes Proposed by Senate," The Johnsonian, February 12, 1965; "Opinions Expressed On Drinking Rules," The Johnsonian, February 19, 1965; "Radius Bill Gains Approval, Senates Passes Policy Change," The Johnsonian, April 9, 1965; "President Explains Defeat of Radius," The Johnsonian, September 17 1965; "Radius Rule Repeal," The Johnsonian, August 29, 1966; Winthrop University, Student Handbook, 1961-1962, 1966-1967; For additional material on alcohol and the Winthrop student body, see the following: "Student Leaders Express Opinions On Allowance of Alcohol On Campus," The Johnsonian, October 20, 1969; "Letters," The Johnsonian, October 27, 1969; "Vast Majority in Favor of Drinking Proposal," The Johnsonian, October 12, 1970; "Senate Passes Drinking Bill," The Johnsonian, October 19, 1970; "Drinking Rights Forfeited Upon Entering WC," The Johnsonian, October 26, 1970; "SGA officers, students vote to enforce rules," The Johnsonian, February 1, 1971; President Davis to Parents of Winthrop Students, October 20, 1970 in The Johnsonian, October 26, 1970.

17 Winthrop University, Student Handbook, 1961-1962, 1966-1967, 1968-1969; "No Blanket Permissions," The Johnsonian, September 5, 1966; "Dean Gibson Gives Reasons for Rule," The Johnsonian, September 5, 1966; "Spot Checking," The Johnsonian, September 12, 1966; "Student Action Needed," October 3, 1966; "Crawford Re-examines 'Blanket Permission," The Johnsonian, April 17, 1968.

18 "Social Rules Should Include Library," The Johnsonian, May 1, 1964; "Social Standards Bill," The Johnsonian, April 18, 1965; "Dressing Freedom Condoned," The Johnsonian, December 9, 1968; "Pants Raid WC Campus," The Johnsonian, March 17, 1969; Winthrop University, Student Handbook, 1959-1960, 1961-1962, 1963-1964, 1967-1968.

19 "Radius Rule Repeal," The Johnsonian, August 29, 1966; Winthrop University, Student Handbook, 1968-1969, 1970-1971; 1974-1975; 1975-1976; "Self-Regulating Hours: No More Lame Excuses," The Johnsonian, October 5, 1970; "Senate Looks Ahead," The Johnsonian, October 5, 1970; "Senate Passes Drinking Bill," The Johnsonian, October 26, 1970.

20 "Winthrop Students Nix Co-education," The Johnsonian, December 6, 1963.

21 "Winthrop Students Nix Co-education," The Johnsonian, December 6, 1963.

22 Walter H. Schrader, Jr. to Harold B. Gilbreth, January 29, 1966 in Coeducation, Subject File, W429.2-1, Box 2, Folder 9, DAWU; "Coed Winthrop College Is Feasible_Davis," Charlotte Observer, February 15, 1967. 
23 "Winthrop Policy Taken to Court," Charlotte Observer, August 3, 1968; "Now Winthrop Grads Include... Yes, A Man," Charlotte Observer, August 12, 1969; "Now the Alma Mater Doesn't Quite Fit," Charlotte Observer, September 21, 1969.

24 "WC Coeducation Urged," The Johnsonian, February 17, 1969.

25 "WC Coeducation Urged," The Johnsonian, February 17, 1969.

26 "Leaders Unanimously 'Pro' on Coeducation Issue," The Johnsonian, August 19, 1969.

27 David A. Grover, "A Study of the Attitudes of Winthrop College Students toward Winthrop's Becoming Coeducational," (Unpublished ms., Winthrop University, 1969), cited in Jane Harris Odom, "The Struggle for Coeducation at Winthrop College: Two Decades of Progress, 1954-1974.” (M.A. Thesis, Winthrop College, 1982).

28 Williams v. McNair, 316 F. Supp. 134 (D.S.C. 1970), afid per curiam, 401 U.S. 951 (1971).

29 "Senate Votes to Let Males Attend Winthrop College," Greenville News, March 23, 1972; Department of Health, Education, and Welfare to Presidents of Institutions of Higher Education Participating in Federal Assistance Programs, August 1972, W429.2-1, Box 1, Folder 3, DAWU; "Winthrop Students Cheer Over Passage of Full-Coed Bill," Evening Herald [Rock Hill], March 14, 1974.

30 Interview with Walter Schrader, Jr., February 6, 1998 in Ginger Marr, "Educating the Fairest Flowers of the Southland: An In-Depth Look at Higher Education for Women in the South and the Evolution of Coeducation at Winthrop College and other Southern Institutions." (M.A. Thesis, Winthrop University, 1998), 39-40; Charles S. Davis to State House Representative Harold D. Breazeale, February 20, 1968, W429.2-1, Box 2, Folder 7, DAWU; Roy Flynn to President Charles B. Vail, March 11, 1975, W429.2-1, Box 8, Folder 46, DAWU; Memo to Charles Davis, July 22, 1968, W429.2-1, Box 2, Folder 9, DAWU.

31 [Form Letter by David Long], W429.2-1, Box 2, Folder 6, DAWU; also included in this folder are sample envelopes of the campaign and receipts for supplies paid for by Grier and Winthrop's Public Relations Office.

32 Amy Thompson McCandless, The Past in the Present: Women's Higher Education in the Twentieth-Century American South (Tuscaloosa: University of Alabama Press, 1999), 247; [Montage], The Johnsonian, April 20, 1970. 